\title{
Kierkegaard, the Spirit of Time and the Individual: Implications for Clinical Psychology
}

\author{
Myriam Moira Protasio ${ }^{1}$, Ana Maria Lopez Calvo de Feijoo ${ }^{1}$, Elisabete Marques de Sousa ${ }^{2}$ \\ ${ }^{1}$ Post-Graduate Program in Social Psychology, Psychology Institute, State University of Rio de Janeiro, Rio de Janeiro, Brazil \\ ${ }^{2}$ Philosophy Center (CFUL), School of Arts and Humanities, University of Lisbon, Lisbon, Portugal
}

\section{Email address:}

myprotasio@yahoo.com.br (M. M. Protasio), ana.maria.feijoo@gmail.com (A. M. L. C. de Feijoo), elisabetemdesousa@gmail.com (E.M. de. Sousa)

\section{To cite this article:}

Myriam Moira Protasio, Ana Maria Lopez Calvo de Feijoo, Elisabete M. de Sousa. Kierkegaard, the Spirit of Time and the Individual: Implications for Clinical Psychology. Journal of Health and Environmental Research. Vol. 4, No. 3, 2018, pp. 84-90.

doi: $10.11648 /$ j.jher.20180403.11

Received: May 8, 2018; Accepted: July 2, 2018; Published: July 26, 2018

\begin{abstract}
The aim is to analyze how Søren Kierkegaard, by the voice of his pseudonym "A", in the chapter the tragic in ancient drama reflected in the tragic in modern drama from Either-Or. Part I, discusses time and the individual, namely by contrasting Zeitgeist, as the spirit of time, and Zeitgeist, as the spirit in time in his presentation of two existential situations of Antigone, namely, the modern character he creates and the Greek character. Kierkegaard claims that the lamentations of the modern Antigone show less sorrow but more pain than the classical Antigone. This difference allows him to posit modern spirit as ready for reflection and in tension with the ancient spirit which is more prone to action. Hence, the tension between the ancient tragic and the modern tragic keeps the universal character without abandoning the individual and, thus, brings to light the individual in history, and this is exactly what is enhanced in this article as of great interest for psychologists, in particular, in clinical existential practice. After an introduction mapping the question, there follow 4 sections focused on the spirit of time, the tragic, Antigone, and Antigone and the spirit of time; and, finally, section 5 presenta the final conclusions, focusing on the relevance of the discussion of the idea of the spirit of the time, and of Kierkegaard's questioning of this idea, for psychology.
\end{abstract}

Keywords: Kierkegaard, Antigone, The Spirit of Time, Existential Psychology

\section{Introduction}

The point of departure for the present research is a chapter of Either-Or. Part I, a text from 1843 signed by pseudonym "A", entitled The tragic in ancient drama reflected in the tragic in modern drama $[1,2,3,4]$ and the concept of Zeitgeist (spirit of time), as used by thinkers of the $19^{\text {th }}$ century. The aim is to show how Kierkegaard analyzes time, by going from Zeitgeist as spirit of time to Zeitgeist as spirit in time, in his presentation of two existential situations of Antigone, the modern character he creates, and the Greek character. Following a few theoretical considerations on the spirit of time, the discussion focuses on how "A" follows the path of a selection of interpretations of the attitude of Antigone in the Greek world and in modernity, in order to claim that the pain depicted in the character's monologues and lamentations of the modern Antigone is greater than the one shown by the classical character, while the sorrow of the modern Antigone, that is, the character's acceptance of destiny and her strength to fulfill it with no further pondering, loses against the sorrow of the Greek Antigone. The contrast thus presented enables Kierkegaard to posit modern spirit as ready for reflection and in tension with the ancient spirit which is more prone to action.

Kierkegaard's text stood, and it possibly still stands, as a dissonant voice amid mainstream philosophical discourse which relies on the language of reason as a conciliatory expression of all the contradictions of human life. The problem of relying on reason as the only possibility of explaining existence, in Kierkegaard's view, is that it often implies total oblivion of what it means to exist in real life. It is to remember the actuality of the meaning of existence that the Danish philosopher upholds the importance of the single 
individual who exists here and now, and for whom existence matters, not as an abstraction, but as a life that needs to be lived every single day.

This is indeed a very pertinent point for the contemporary discussion concerning human existence and has deserved the attention not only of philosophers and students of philosophy, but also of psychologists who focus on human existence as a field of possibilities and where the old and the modern are always in tension. In the final remarks of this article, the relevance of this tension for the psychological clinical practice is highlighted.

\section{Kierkegaard and the Spirit of Time}

Søren Kierkegaard's lifespan (1813-1855) is contemporary of the revolution and the social turmoil that agitated Europe, in particular France and Germany, in the $18^{\text {th }}$ century. The revolutionary movements had the mark of a humanist ideal, advocated in the tripartite principle of the French revolution - Liberty, Equality and Fraternity. Hegel's thought, especially in Phenomenology of the Spirit, [5] re-instates the movement of the spirit claiming that it is the birth of a new time and a result of the multiple transformations of civilizations, with their laws, political regimes, ethics and culture. In the shadow of these revolutions, the idea of Zeitgeist (spirit of time) gains momentum, as depicted in the movement of historical events. The problem of history, which was central to eighteenth-century philosophical thought, will remain crucial throughout the nineteenth century; some thinkers aim to prove that the ordering force of the world is history and that it is by history that the universal is fulfilled. Hence, the concept of the spirit of time encapsulated the idea that by understanding how history evolves one may understand what is behind the movement of historical facts and events, something that is neither wordly nor material, something that is of the order of the universal Zeitgeist. According to Rossati [6], "the concept of the spirit of time functioned as a concept of temporal demarcation from which European intellectuals sought to apprehend their situation, that is, from collective openness towards the future".

The revolutionary thought that arises in modernity opposing dogmatic thought, history, would guarantee the sublation and conquest of eternity already in earthly life, a claim that is imbibed in philosophical systems and in the romantic literature of the early $19^{\text {th }}$ century. Hegel paved the way and rectified the differences, capturing in the unity of sovereign reason the illogical fragments of the world. Society and the individual, art and religion, could be understood and philosophy could explain it by means of viewing the march of history retrospectively; taking this type of analysis as point of departure it was possible to reconcile the contradictions of human life in its highest expression, that is, human reason [5].

The claim of the present study is to show that in a view of human life that sees man as a component of Zeitgeist, what is gained in terms of a totality, conceived universally and formally in order to provide total and absolute explanations, is at the same time lost in terms of the actuality of human existence, which is by definition singular. The claim is that Kierkegaard's dialogue with the thinkers of his time and with the contemporary understanding of history as a necessary march towards the absolute of the spirit demonstrates that historical time is not an abstraction. On the contrary, only in the concrete lives of individuals does the spirit of time gain materialization; life can then be described as an existential plot that gives voice to the possibilities of time in its finitude, yet, without failing to be engaged in the tension ensued by the infinitude of the time. Kierkegaard responds to this question by presenting, discussing and proposing new categories in order to understand the whole of what the existence of the individual means in its various modulations or spirits, which are both singular, first and foremost of the individual of each case-study, and universal, starting by the community of readers he so often addresses. For Kierkegaard, time, defined by Hegel as a constant disappearance towards a universal absolute, is not real time. Johannes Climacus, another Kierkegaardian author ${ }^{1}$, points out that the "universal-historical distraction" has forgotten what it means to be a human being, not the human being in general, but every human being, me, you, him. Löwith [7] explains that once life is taken historically one cannot set up right from the start what will eventually result later.

Kierkegaard's era was immersed in the optimism of the promise of a full and accomplished life here on earth by following social established norms, according to which no human starts from zero but receives everything from previous generations, and simply has to adjust to such norms and principles in order to obtain eternal goods already in earthly life. Accordingly, the tragedy of life seemed to have been completely overcome by the march of history, and the new generation always stood a step higher than the previous one. But in many of Kierkegaard's writings, what is at stake is the question of the conditions of possibility not of the society, but of the individual, as in this text from 1851 [8]: “(...) my position has indeed been the single individual, with polemical aim at the numerical, the crowd, etc.". Instead of abandoning the very movement of existence as the Hegelian sublation does, Kierkegaard's quest pursues the possibility and the possibilities of existence, and Anti-Climacus, who Kierkegaard considered to be his highest pseudonym author, states that existence is possible only in tension, in relation. Or rather, existence gains materialization as that which in the relation is related to the relation that it is [9]. In other words, existence, in its dispositions, in its different modalities, cannot be sublated and no one initiates it in a privileged place in relation to the previous generations, as another pseudonym author, Vigilius Haufniensis [10], tells us.

Kierkegaard's discussion of the spirit of time is particularly clear in the comparison he makes in the chapter

\footnotetext{
1 Johannes Climacus signs three different texts: Johannes Climacus, or De omnibus dubitandum est, from 1842-43; Philosophical Fragments, or a Fragment of Philosophy, from 1844; Concluding Unscientific Postscript to Philosophical Fragments, from 1846.
} 
The tragic in ancient drama reflected in the tragic in modern drama between two eras, the modern and the Greek. He shows us that every single human being begins existence in the same place, and, in all his analysis, he pays special attention to the particularities that mark the differences between these two eras. Kierkegaard's analysis does not follow what happens in the Greek world in a naive or nostalgic way, by taking as reference the modern world, and indeed Gazolla [11] warns us against the risk of understanding Greek tragedy through modern determinations, namely against the dangers posed by the superficiality of an interpretation of the tragic drama that does not consider the specific historical contingencies of the Greek world. Gazolla [11] states that what we write about the Greek horizon are "attempts to touch something essential of the tragic as if we were close to a Greek and their way of understanding". In his The Discovery of the Mind, Bruno Snell [12] also accounts for the difficulty of his time in understanding the Greek authors by saying that, despite all the historical understanding reached by the turn of the eighteenth to the nineteenth century, which overcame the rationalist conception of an "ageless, unchanging "spirit", the interpretations are based on modern representations and disregard the fundamental difference between what is Homeric and what is familiar to us. Snell [12] notes the importance of a radical understanding of the beginnings of thought among the Greeks, those who "first created what we call thought: the human spirit as active, inquisitive and studious spirit", translation modified according to the original German text).

In order to understand the gain and loss of pain and sorrow in the comparison between Greek tragedy and modern tragedy, it is of interest to consider Aristotle's Poetics. According to Machado [13], Aristotle analyses the poetics of tragedy as a technique of poetics in general, "without considering the tragic poem as an expression of a wisdom or worldview that modernity will call tragic". To Aristotle [14] "tragedy is the imitation of a high and complete action, endowed with extension, in a language embellished by different forms in each one of its parts, that uses action and not narration and that, by means of compassion (elios) and fear (phobos) causes the purification (katharsis) of such passions". And the structural elements that the tragedy contains in its constitutive parts are: the plot (mythos), the characters (ethe), elocution (lexis), thoughts (dianoia), spectacle (opsis) and music (melopeia), which is the most important adornment of language. It is important to emphasize that to Aristotle what matters is that the formal aspect of the tragedy should allow to describe its structure without losing sight of its purpose, that is, the catharsis of the spectator's passions aroused by the suffering of the characters.

Many modern thinkers, including Hegel [15], continued to think art in its actuality and process of transformation, always in the process of becoming. Kierkegaard also expressed interest in understanding the tragic sense. By putting into question the mainstream theses of his time, namely, that the movement of history describes an ascending curve at the price of engulfing the old, the Danish thinker proposes another way of interpreting history by comparing tragedy in two eras. From the point of view of aesthetics, his response to interpretations that retrieve the Greek world is based not on tragedy as an aesthetic form, but on the possibility of the appearance of new tragic dispositions in modern tragedy.

Kierkegaard's discussion of history via the tension he underscores between the ancient tragic and the modern allows shedding light to his discussion of the spirit, which is not the spirit of a time, but the spirit that appears differently along the changes of time. In seeking temporal interpretations of the spirit in its diversity, Kierkegaard considers that interpretations must be constructed in accordance with the historical context. The next section follows Kierkegaard's reasoning in posing this problem, departing from the question of the meaning of the tragic in the chapter The tragic in ancient drama reflected in the tragic in modern drama. Was tragedy a disposition only among the Greeks? Does this imply that it is a disposition which has been superseded by modern dispositions? Or, can we still use the language of tragedy to talk about the dispositions of the modern spirit?

\section{Kierkegaard and the Tragic}

Kierkegaard $[1,4]$ is not alone in the resumption of the ancient world; in fact, in the chapter on the tragic, he refers especially to the aesthetic thinkers, namely Hegel and his followers in Denmark, "who always returned to the definitions of and requirements for the tragic established by Aristotle as exhausting the concept". But what is particular to Kierkegaard is that he discusses the spirit of time via an understanding the tragic in tragedy and the tragic in thought.

The tragic in ancient drama reflected in the tragic in modern drama opens with a rhetorical question: will the tragic always remain the tragic? The answer is found in the author's claim that if we respond positively, we establish a general relationship with the sense of tragic, a relation that pretends to ignore the difficulty of the tragedy itself, which, for him, links the ancient and the modern tragedy inseparably: human suffering. Conversely, " $A$ " shows that, among the moderns, reflection marks a form of dealing with existence that bestows on it an ethical contour based on a certain distance from continuity (the eternal, as he prefers to say) [1, 2, 3, 4].

Following Aristotle, as well as Hegel, when discussing two disparate genres, such as comedy and tragedy, Kierkegaard emphasizes the element he considers central in comedy, which, for Kierkegaard, is doubt in its absolutely individual and isolated character. For "A", taken that Aristotle proclaims character and situation as central elements of comedy, in its endeavor to create laughter, what is achieved is a general determination, to which we can return countless times without any change. But once the question now concerns what makes a person laugh, then, there emerges some insufficiency in the general determination and, rather, it 
is diversity and mutability that appear in relation to all representation. " $\mathrm{A}$ " suggests that this becomes very clear if a person observes what makes them laugh or what makes the people around them laugh. That is, the general determination is insufficient when it comes to understanding the very life of the comic in its movement anchored as it is in the individual.

In what concerns ancient tragedy, "A" raises a similar question, when stating that Aristotle referred to thought and character as its central elements, whose main theme is telos. Aristotle was especially focused on the ultimate effect of the tragic scene, e.g. by stating that the spectator is part of the tragedy because of the action, whose purpose is to rouse the catharsis that awakens passions in terms of fear and compassion and, thus, spiritual cleaning [14]. In his essay on the tragic, Kierkegaard does not follow Aristotle's footsteps in the latter's endeavor to attain the general determination of tragedy (catharsis); he pursues a more complex task. Kierkegaard wants to show that Hegel, in Aristotle's steps, that is, by seeking to outline in detail the formal aspects of tragedy, distanced himself from the concept of the tragic as a living category, since Hegel's proposal is the conciliation of opposing motives in the movement of contradiction and reconciliation.

"A" $[1,4]$ constantly maintains the tension between the sense of the tragic in Antiquity and among the moderns, which he takes not in its formal aspects, but in the way the tragic comes out in the spirit of time, i.e., as an event which is given in time and therefore appears in different existential modalities, as in this claim: "In ancient tragedy, the action itself has an epic element; it is just as much event as action", while "in contemporary times the situation and the character are the prevailing elements". He shows that contemporary tragedy is marked by an exhaustive reflection that is present in the dialogues and he draws attention to the comic character of an era which thinks that an individual conquers everything by her own forces and, to the same extent, fails because of her own efforts; as "A" $[1,4]$ states: "One would think that the generation in which I have the honor of living must be a kingdom of gods. But this is by no means so; the vigor, the courage, that wants to be the creator of its own good fortune in this way, indeed, its own creator, is an illusion and when the age loses the tragic, it gains despair.".

According to " $A$ " $[1,4]$, by losing touch with the sense of the ancient tragic and by placing an excess of responsibility on the individual, disregarding that "every individual, however original he is, is still a child of God, of his age, of his nation, of his family, of his friends, and only in them does he have his truth", his generation gets despair in return. $\mathrm{He}$ adds [1, 4]: "Our age has lost all the substantial categories of family, state, kindred; it must turn the single individual over to himself completely in such a way that, strictly speaking, he becomes his own creator". "A" $[1,4]$ claims that this difference appears in the way pain and sorrow are experienced in each of these historical moments, the Greek and the modern: "The Greek hero rests in his fate; his fate is unalterable; of that there can be no further discussion. This element is really the component of sorrow in the pain.", for there is no doubt in the Greek spirit; and this becomes ostensibly visible once the author asks: "Why is this happening to me; can it not be otherwise?". It is in this instant that pain increases and sorrow decreases, or, using "A"'s words [1, 4], "in ancient tragedy, the sorrow is more profound, the pain less; in modern tragedy, the pain is greater, the sorrow less" (...) for "pain always indicates a reflection upon the suffering that sorrow does not know".

Pseudonym "A" $[1,4]$ refers to guilt (or tragic error) as the central element so that the difference of the tragic comes out in the two eras: in Greek thought, the wrath of the gods is terrible, but the pain is not so great, because the Greek hero is totally immersed in his situation and, hence, his guilt is original, encapsulating a self-contradiction, "of being guilt and yet not being guilt", because the wrath of the gods had no ethical character; on the contrary, it had aesthetic character, that is, it was guided by the laws of existence itself, for "the Greek hero rests in his fate; his fate is unalterable; of that there can be no further discussion". But, " $A$ " $[1,4]$ says, our time is a time of melancholy, and it knows enough about guilt and knows well what responsibility means, although no one wants to take it: "The wrath of the gods is terrible, but still the pain is not as great as in modern tragedy, where the hero suffers his total guilt, is transparent to himself in his suffering of his guilt".

Error (hamartia) is present in ancient tragedy; yet, the dialogue never transforms into reflection or repentance. Error is characterized by a type of suffering which is, simultaneously, an action without the intermediation of a subjectivity that is reflected in itself. In ancient tragedy, individuals do not represent characters; they are part of the action and, as Snell [12] says, actions requires that there must be justice in the world, which in turn implies making demands on the gods and on men. As for modern tragedy, "A" says that the hero is reflected in himself and is out of any immediate relationship, be it with the state, the family, the destiny and eventually with himself. Thus, for "A", the modern tragic hero rises and falls by his own acts. If the hero falls, it is by his forces. Thus, we lose the very tragic character, which among the Greeks lies in the order of destiny and among the moderns gives place to personal drama.

" $A$ " proceeds in his exemplification of the difference between Greek and modern tragedy by making use of Sophocles' trilogy Oedipus at Colonus, Oedipus Rex, Antigone, analyzing in detail the case of this last tragedy, showing how the spirit differs in Greek time and modernity by sustaining the tension between sorrow and pain.

\section{The Spirit in Time: Antigone}

"A" [1, 4] justifies his choice of a feminine character, Antigone, to illustrate the difference of the spirit of time in two distinct era, as follows: "I am using a female character because I believe that a female nature will be best suited to show the difference"; that is, for him, the tension between sorrow and pain, between substantiality and reflection, is 
more visible in a heroine than in a hero. Two problems crop up in Antigone's tragedy: the determination of life in society (polis), which arises from the will of Creon; and the determination of Antigone, who wants to save what is meant in the idea of the Greek family (oikós), meanings that go beyond the logic of laws and life in society. Antigone, the daughter of Oedipus's marriage to Jocasta, values family tradition, which is not contemplated by the community or by king's orders; rather, it gains its singular meaning as Antigone becomes the kernel of the plot: "Oedipus has killed the sphinx, liberated Thebes; Oedipus has murdered his father, married his mother", says Kierkegaard ("A"). But the tragic element lies in this: although everyone knows that Oedipus killed the sphinx and freed Thebes, only Antigone knows that he killed his father and married his mother. This knowledge was not passed on to her by tradition, but it came to her in a tragic way, as a premonition announced by the chorus, and "this horrible secret had momentarily gripped her soul, until certainty hurled her with one blow into the arms of anxiety" and there emerge the possibility and the separation between time, in the past and in the future, and space, Antigone's and her secret.

Antigone follows her destiny, which is neither reduced to disobedience to Creon's law or to collision with her brother, nor does it constitute a decision; it is, instead, an individual destiny. "A" [1, 4] says: "It is not an individual who goes under, but a little world; it is the objective grief, unloosed, that now strides ahead, like a force of nature, in its own terrible consistency". The act of burying the brother is not so much a free action "as a fateful necessity, which visits the iniquities of the fathers upon the children" that surrounds Oedipus and his children. Here there is sorrow, announced by the choir, but not pain. The Greek Antigone does not grieve over her destiny, since this demands inner reflection; her life is turned outwards, defined as it is by complying with ancestral tradition. Thus, two laws, Creon's and ancestral laws, confront each other in what Antigone experiences as her task. The relative nature of the quarrel between the king and the nephews, the brothers of Antigone, is of no value to her, because she accepts as eternal the ancestral tradition which says that relatives should be buried by their own. Hence we can say that the spirit of time (universal) is actualized in time (Antigone's, a single individual). It is not a question of sublating previous dispositions or relativisms; it has to do with the (tragic) tension between the constituent elements that sustain duty and possibility at the time of decision, which is always of the realm of the singular.

"A" $[1,4]$ continuously returns to the discussion of the modern Antigone. For him, as in the case of the Greek Antigone, the modern Antigone does not fit into the world in which she lives, because she leads a clandestine life, silent and hidden in the secret of her own soul, in a proud disposition that she experiences because she has been chosen to save the honor and glory of her lineage. But, he says, our Antigone is turned inward. Her secret gives her a "preternatural bearing. She is proud in her grief, she is jealous of it, for her grief is her love". Her life is to grieve over her father's fate. "A" $[1,4]$ stresses that there is also sorrow in Greek Antigone, but this sorrow is not her life; it arises at the exact moment when she comes to the determination to be buried alive, and with it she surrenders to a destiny that gives her no place among the living or the dead. The modern Antigone experiences sorrow throughout her life and can constantly repeat to herself how little she got from life, and here lies her pain. In her pride she is more than a young woman in the general sense and, because of it, she is great enough to "almost thank the gods because she has been selected as this instrument". Yet, although she feels lonely, she is not alone.

\section{Conclusion}

The objective of this study was to bring to the discussion the historical issue, a central theme in the nineteenth century, as discussed by Kierkegaard who addresses the subject by focusing on the tension between the ancient tragic and the modern tragic, keeping the universal character without abandoning the individual and, thus, bringing to light the individual in history. The question posed concerned the reasons why psychology students are interested in the theme of the spirit of time (Zeitgeist). As current psychology gives attention on the problems of people that emerge in our time, psychologists and researchers need to think about what characterizes modern time to understand the individual and his own questioning over the time he lives in.

Kierkegaard underscores the difference between the ancient and the modern tragedy, but he does not address formal aspects, as Aristotle and Hegel did. When Kierkegaard contemplates how the interpretation of the tragic disposition is present in two such different eras, so distant in time, he is actually considering the spirit of time not only as a determination of an era but also as a spirit in time, that is, as life that gains materialization as it becomes existence, insofar as the existent solves the problems that are her own existential problems. What matters to him is the tension in which life happens, the tension that sustains the being-capable of freedom as a possibility to possibility and the determinations and contingencies that encompass it. In life, taken abstractly, the elements can be mapped, and the answer can come from the logical-speculative movement. In existential life, the elements are in constant tension and the individual cannot exist outside this tension, and it is in this tension that the single individual must find the measure of their action. Kierkegaard's response is to reaffirm that reality is chance, becoming, and the characteristic of becoming is to be open.

For a practice of psychology that seeks to attune itself to existence, this statement is especially important. Firstly, it indicates the insufficiency of the necessary causal connections between the elements of existence, in a movement contrary to that of the psychologies inspired by the natural sciences. And especially because it demands from the psychologist a modality of listening that remains in tune with the determinations of his time, so that the elements that sustain the different ways of living can be understood. 
To describe the way the human being emerges in different historical horizons of meaning, the language of art and the art of writing become useful tools to express thought as an expression of human experience. In the ancient Greeks, it is in tragedy that the tragic expression of such experience is found. As Nietzsche [16] states: "we must remember the enormous power of tragedy to stimulate, purify, and discharge the entire life of the people". To make use of tragedy to understand human experience means to break up with the many dichotomies that have settled in the modern world, among them, guilt and innocence, the Apollonian and Dionysian poles, good fortune and misfortune, pain and pleasure. Such changes in the understanding of life in these terms dates from Antiquity and to a certain point mask the tragic character of life and have passed on to the Christian cosmovision; and, this time, the dichotomies of innocence and guilt, right and wrong, are totally placed on the individual. As Kierkegaard tells us, we leave the disjunctive conjunction for disjunctive abolition [17].

Since the Renaissance some philosophers had proposed to return to the Greeks for different reasons. The Renaissance thinkers, believing that medieval thought had obscured the truth by means of their dogmas, returned to Greek thought to find the truths that were established by ancient Greece philosophy. The German Romantics turned to the Greeks in the belief that along this path they could find elements that would allow them to overcome the social difficulties of nineteenth-century Germany. In such interpretations of the Hellenic world, there is an idealization of the Greek culture, seen in the humanist view that seeks to prescribe the duty of the human being by means of a normativity in which the reference is, citing Gazolla [11], the "golden childhood of the West". Hence, the German Romantics believed that by taking Greek thought once again they could draw up norms and parameters to use as guidance for human existence, so that they would attain something more primeval, be it infancy, the condition of the bon sauvage, and so on. Or, as in Hegel, a return to the Greeks so as to find, in the historical movement, the process in which the absolute spirit develops.

In Kierkegaard, we find a different kind of return to the ancient Greeks, because his proposal is to clarify what marks the spirit of time, with the aim of deconstructing the idea that the modern world is superior to the previous and that it is in the modern world that absolute and unquestionable truths are to be found. In Kierkegaard's account of the epic poets, preChristian notions are to be found in their tragedies: hybris (excessive), hamartía (tragic error, lack), tyche (luck, fortune) and unity, next to polis, and family and the individual, since the act does not happen only by the deliberation of the hero. Modern tragedies, however, operate with the notions of free will, sin, and individual responsibility for acts - the tragic hero is the agent and it is in his actions that we find the reasons for his fall. He is free, responsible, and the only one who decides for his actions. Kierkegaard ("A") $[1,4]$ then concludes that the effort to explain the tragic is fragmentary and not a finished work, since all human effort is fragmentary, and is "precisely this which distinguishes it from nature's infinite coherence".

In "A"'s presentation of Antigone to the community of the dead ( $\Sigma \nu \mu \pi \alpha \rho \alpha v \varepsilon \kappa \rho \omega \mu \varepsilon \dot{v o l})$, he refers to the disposition that worships natural laws and finitude "whose inexorable destiny consists in disappearing" [18]. Thus, for " $A$ ", the spirit of time is made present in time by individuals who are at one time themselves and humans as a possibility of their time. He also showed that Antigone, one of the great characters of the Greek tragedy, assumes different forms according to the spirit in the time in which the play is staged.

For research in existential psychology, the focus on the experience described by " $\mathrm{A}$ " as something that concerns the aesthetic (sensitive) experience is of interest because it is exactly the sensitive, the singular, which occupies a privileged place in clinical psychology. Psychology as a scientific discipline seeks, as a rule, to establish generalizations and categorizations, and even when it says that its interest is the individual, it does so at the price of abandoning the singularity of each case. It is to bring the singularity of each case to the core of clinical practice that we need to dialogue with Kierkegaard's texts. They prove to be an eloquent and useful means of gaining insight into how to reach the experience of the other in their concrete and substantial reality, whose substantiality appears and disappears in the very interplay of the relationship, in which what is in question may become clear as well as obscure.

By means of Kierkegaard's reflections, we reach the sense of spirit in time. This always implies the tonality or the atmosphere of a time, and comes to life in the process of articulation of the individual with her time. This is central to psychology, not as a science of the universal, but as a science that does not want to lose sight of the single individual and that knows that this individual does not exist out of her time. For the clinical psychologist, this implies sustaining existence as a disjunctive conjunction in which what is at stake is to assess how much of each of the dispositions (possibilities) is present in a particular way articulating a relation to existence. It is in this sense that the difference made by Kierkegaard between sorrow and pain in Greek Antigone and in our Antigone, is enlightening, since he demonstrates so clearly that in the modern Antigone there is excess of pain and lack of sorrow, unlike the Greek Antigone, where sorrow is greater and pain lesser. This difference also allows for questions to be answered in future research. What does this excess of pain and lack of sorrow mean to us at the beginning of the $21^{\text {st }}$ century? What is its impact on phenomena such as boredom, or the increase in suicide in our time? These questions only attest to the importance of reflections on the relation between existence and the spirit of a time, not as universal dispositions but as a possibility at any time, which are central to the practice of existential psychology in the way as understood here.

\section{Acknowledgements}

To FAPERJ by the Myriam Moreira Protasio's postdoctoral scholarship. 


\section{References}

[1] Sören Aabye Kierkegaard, The tragic in ancient drama reflected in the tragic in modern drama In Either/Or, Part 1, trans. by Howard V, Hong. USA, New Jersey: Princeton University Press, 1843/1987.

[2] Sören Aabye Kierkegaard, De la tragedia, trans. by J. Zavália. Buenos Aires: Editora Quadrata, 1843/2005.

[3] Sören Aabye Kierkegaard, El reflejo de lo trágico antiguo en lo trágico moderno In $O$ lo uno o lo otro. Un fragmento de vida, trans. by Darío González. Madrid: Editorial Trotta, v. 1, $1843 / 2006$.

[4] Sören Aybe Kierkegaard, O reflexo do trágico antigo no trágico moderno In Ou - ou Um fragmento de vida, primeira parte, trans. by Elisabete M. de Sousa. Lisboa: Relógio D'Água, 1843/2013.

[5] Georg Wilhelm Friedrich Hegel, Fenomenologia do Espírito, parte 2. Trans. by Paulo Meneses. Petrópolis: Vozes, 1807/1992. (Phenomenology of Spirit).

[6] Gabriel Guedes Rossati. Kierkegaard e o reconhecimento do espírito do tempo, chapter 2 in $O$ conceito de modernidade nos escritos primeiros de Kierkegaard, p. 40. Thesis to the Interdisciplinary Program in Human Sciences of the Federal University of Santa Catarina UFSC, 2012. Available at https://repositorio.ufsc.br/bitstream/handle/123456789/106733 /310359.pdf?sequence=1. (Kierkegaard and the recognition of the spirit of time)

[7] Karl Löwitt. De Hegel a Nietzsche: La quiebra revolucionaria del pensamiento em el siglo $X I X$, trans. by Emilio Est. Buenos Aires: Katz Editores, 1939/2011, p. 17. (From Hegel to Nietzsche).

[8] Sören Aabye Kierkegaard. On my work as an author. In The Point of View. Trans. by Howard V. Hong and Edna H. Hong. USA, New Jersey: Princeton University Press, 1851/1998.Sören Aabye Kierkegaard. The sickness unto death:
A Christian psychological exposition for upbuilding and awakening. Trans. By Howard V. Hong and Edna H. Hong. New Jersey: Princeton University Press, 1849/1980.

[10] Sören Aabye Kierkegaard. The concept y of anxiety: A simple psychologically orienting deliberation on the dogmatic issue of hereditary sin. Trans. By Reidar Thomte in collaboration with Albert B. Anderson. New Jersey: Princeton University Press, $1844 / 1980$.

[11] Rachel Gazolla, Para não ler ingenuamente uma tragédia grega, São Paulo: Edições Loyola, 2001.

[12] Bruno Snell, The Discovery of the Mind, trad T. G. Rosenmeyer, New York: Dover Publications, 1982.

[13] Roberto Machado, O nascimento do trágico, Rio de Janeiro: Zahar, 2006.

[14] Aristóteles, Poética, trans. Ana Maria Valente. Lisboa: Fundação Calouste Gulbenkian, 2008. (Aristotle, Poetics).

[15] Georg Wilhelm Friedrich Hegel, Cursos de Estética, vol. IV. Trans. Marco Aurélio Werle e Oliver Tolle. São Paulo: EDUSP, Editora da Universidade de São Paulo, 1835/2004. (Hegel's Lectures on Aesthetics).

[16] Friedrich Wilhelm Nietzsche. The Birth of Tragedy and Other Writings. Trans. Ronald Speirs. New York, USA: Cambridge University Press, 1872/1999.

[17] Sören Aybe Kierkegaard, La época presente. Santiago do Chile: Editorial Universitária, 1846/2001. (Two Ages)

[18] Maria Jose Binetti. El estadio estético de Kierkegaard en las categorías lógicas de Hegel: inmediatez, reflexión y posibilidad forma. In Enfoques, vol. 22, no. 1 - Libertados San Martín, otoño 2010, p. 31-51.

[19] Ana Maria Lopez Calvo de Feijoo \& Myriam Moreira Protasio. The Rescue of the Aesthetic Character of Existence in Kierkegaard's Philosophy, J Relig Health (2015) 54:1470 1480. DOI 10. 1007/s10943-015-0026-5. 